\title{
Indonesian tourism marketing communication strategy through LionMag in-flight magazine
}

\author{
Adi P. Tedjakusuma \& Hayuning P. Dewi \\ University of Surabaya, Surabaya, Indonesia
}

\begin{abstract}
The world of tourism cannot be separated from transportation and accommodation. Transportation becomes a means of tourists to reach the desired tourist destination both domestic and international. Airplane becomes the most effective option for tourists as it reaches a wide range of destination. Each airline including Lion Air has its own promotional media to communicate with potential passengers. This research focused on the representation of Indonesian tourism as strategic marketing communication in LionMag InFlight magazine. This study used data collection techniques obtained from various sources such as documents, archival records, interviews, and observations, both in the form of research or non-research research data as well as conceptual or procedural. The results of this study indicated that LionMag continues to be creative in providing information needed by both local and foreign tourists.
\end{abstract}

Keywords: Marketing, Magazines, LionMag.

\section{INTRODUCTION}

The main objective of the marketing concept is to satisfy the customer needs. Media is used as a means to deliver certain messages to different layers of consumers, regions, and demographics in a timely manner. The impact of a message delivery is not only determined by what is being said, but also by how the message is delivered. Advertisers must deliver messages through the media in a way that can attract attention and arouse target market's interests. A magazine is known as one of the media to deliver marketing messages which can reach the national market at a relatively low cost for a relatively long time. It can often be read in various places and times as well as also contain display ads (Martiman 2014).

A magazine is a print media that provides information to the society. These days, there are so many types of magazines read by the community, ranging from magazines on information technology, lifestyle, economy, social politics, and so forth. It is very popular because people realize the benefits of reading magazine. Information is part of the communication that is needed by all age group of society (Yudarnadi \& Santoso 2015). Besides providing information about fashion, culture, or tourism, a magazine can be a media promotion.
The magazine ads for this promotional media are primarily applied to magazines that cover culture and travel. One of them is the in-flight magazine namely LionMag which is only circulated in commercial aviation. Thus, the potential of culture and tourism dominate the LionMag contents. The LionMag management sees a very potential Indonesian tourism to be marketed to passengers of Lion Air, Batik Air, and Wings Air.

\section{CONCEPT OF CRITICAL DISCOURSE ANALYSIS}

\subsection{Marketing Strategy}

Marketing strategy is a comprehensive and integrated plan in the marketing field so that organizational activities can survive and continue. Therefore, the formulation of the marketing strategy should be based on the internal and external environment through Strength - Weakness - Opportunity Threat (SWOT) analysis of the company. (Kotler \& Keller 2011). 


\subsection{Magazine as printed mass media}

A magazine is one form of printed mass media, and mass media is one element of mass communication. Mass communication is the dissemination of messages through media to the public in a massive and abstract way, that is, the number of people reached by the message indirectly. The types of magazines themselves can be distinguished on the basis of publication frequencies and reader audiences (Richardson 2007). Meanwhile, the publication frequency in Indonesia is generally weekly, monthly, fortnightly, and even quarterly. Magazines that are circulated on the market today can be divided into 3 (three) types, namely: First, News Magazine. It refers to a magazine that covers a complete summary and more indepth analysis than news written in a newspaper. The news is usually about business and economics, politics, national and international news. Second, Women's Magazine. It is a magazine that covers information about women such as gardening, fashion, home styling, family, cooking tips, and etc. The design and layout are adjusted to readers who tend to be calm and colorful. The Last, Men's Magazine. It is a magazine that covers information about men such as extreme sports, sexy women, nightclubs, body shaping, dating tips, and so on.

According to Kamus Besar Bahasa Indonesia (Indonesian dictionary), a magazine is a periodical issue covering the various coverage of journalism, information that should be known by readers, articles, literature and so on which according to the time of its publication is distinguished by monthly, fortnightly, weekly magazines and so forth. Magazines normally have volume, front covers of photo illustrations, picture or painting but can also contain a table of contents or main articles, and the paper used is more luxurious than newspapers. The magazine really needs to consider the heterogeneity of readers whose news readings are intended for the public and written by some people with popular language in order to be easily understood by the society.

\subsection{Tourism}

Tourism can be viewed abstractly, that is, as a phenomenon that engages with the human movement within its own country (domestic tourism) or across the national boundary (international tourism) (Wahab 1975). Meanwhile, Mcintosh \& Goeldner (1986) defines tourism as a number of phenomena and relationships arising from the interaction of tourists, business, governments, hosts, and host communities that happen during the process of attracting and serving tourists or visitors. Furthermore, tourism is a mix of activities, services, and industries that form travel experiences such as transportation, accommodation, housing, food and beverage, shops, facilities and services available to individuals and groups traveling outside their homes.

From the above definition, it can be concluded that in tourism activities, there are tourist sources and tourist destination countries. Tourism as a product offered to potential and actual consumers need to have differentiation in order to compete with other tourism products offered by the competitors. Kotler $\&$ Keller (2011) also proposed five differentiation products namely differentiation of physical attributes, services, employee, location, and image.

\section{RESEARCH METHOD}

This study used data collection techniques obtained from various sources such as documents, archival records, interviews, and observations, whether in the form of research or non-research research data, conceptual or procedural.

In analyzing discourse, one thing that needs to be noted is the heterogeneity of the readers' magazine because a magazine has certain target market from age level or gender or even a particular social class. Thus, discourse will greatly affect the reader in interpreting the news or the article. Unfortunately, magazines are now using a lot of proactive languages that leads to counter ideologies against a particular class. This is due to readers that continue to demand reading models which cover things that challenge the discourse analysis (Setiawan 2011). In a discourse, there is the idea, i.e. the substance of discourse content which becomes a meaning (Richardson 2007). The form of interpretation can be knowledge, opinions, emotion and so on. The nature of discourse as outlined is essentially inspired by a formal observation. Based on the formal approach, discourse is the sentence that is coherent, intact and written with a certain structure. Discourse can also move from a functional view, i.e. discourse is seen as a language in use. From that perspective, discourse is understood as a communication event, i.e. the personification of the individual who is communicating. In this case, the language spoken by the speaker is seen as a manifestation of the speaker's action (meaning) (Wodak \& Meyer 2016).

Discourse is seen as the use of language, both in speech and writing which are forms of social practice. Using discourse as a social practice causes a dialectical relationship between certain descriptive (using language) events with the situations, institutions, and social structures that form them (Titscher et al. 2012). Discourse practice may present ideolog- 
ical effects, so it will depend on the active and dynamic process of the author and the reader. This discourse can produce and reproduce the relationship of signs that represent the displayed social position.

The meaning is produced through an active and dynamic process, both from the author's and reader's side. Readers and texts jointly contribute to the interpretation of discourse and the relationship place the reader as a part of its connection to the larger system of values in which they live in society. Since media news including magazines is basically not intended for oneself, media messages are basically intended to communicate with audiences (Wodak \& Meyer 2016).

\section{DISCUSSION}

\subsection{Communication as one of the supporting elements of marketing}

The success of marketing is dependent on the role of communication in which communication refers to a process of thinking and understanding exchanged among individuals, or organizations and individuals (Shimp 2003). A strategy is needed in addition to communication that has a fundamental role in the marketing process because a strategy can create a good marketing communication in distributing products or services.

Communication can also be used as a reminder to consumers about the existence of the product. This reminding process of communication is very important for organizational survival. Organizations can survive because of the consumer, and reaching or attracting consumers is a difficult thing. An important role of communication is also related to persuading existing and also potential customers to make purchases. The message conveyed in the communication is persuasively aimed to convince customers to make purchasing action. Another role of communication is to differentiate (differentiating) the products offered by one company to another. The effort to differentiate this product is done by communicating to the customers that the product offered is different from other similar products (Sutisna 2002).

\subsection{Indonesian Tourism and Marketing}

According to Law Number 10 the Year 2009 on tourism; the nature, flora, and fauna as God's gifts, as well as the historical, artistic, and cultural heritage of the Indonesian nation are the resources and assets of tourism development to increase prosperity and welfare of the people as embodied in Pancasila and the Preamble of the 1945 Constitution of the State of the Republic of Indonesia.

In Indonesia, many tourism potentials become a good destination for local and international tourists (Yudarnadi \& Santoso 2015). This should also be supported by the development of tourism facilities in order to attract more tourists. The development of tourism facilities in the tourist destinations as well as tourist objects must be tailored to the tourist needs quantitatively and qualitatively. Quantitatively, it indicates the number of tourism facilities that must be developed, and qualitatively indicating the quality of service that is reflected in the tourist satisfaction who received the service (Shimp 2003).

Tourism marketing is very complex in nature, compared to the marketing of goods produced by manufacturing companies. This is because the tourism industry's product has distinctive features compared to products of goods. One of the features is the fact that tourism product is interconnected with organizations, agencies, and institutions in society. The success of a marketing program in the tourism field is determined by the similarity of views towards tourism for regional development (Siahaan 2008).

\subsection{Indonesian tourism marketing communication strategy through LionMag in-flight magazine}

It cannot be denied that tourism activities provide benefits and income for a country/tourist destination, although not apart from the loss and negative impact, especially on culture and environment. The most obvious benefit of tourism is its contribution to the national income in bringing in foreign exchange, employment creation and other sectors (through indirect impacts), as well as the possibility for people in the receiving country to improve their income and living standards. Tourism activities that have many benefits for the nation and its citizens must be maintained, even improved, and developed through some efforts to promote both less and well-known tourist attractions to increase the country's income and achieve the goals of tourism.

LionMag in-flight magazine aims to inform Lion Air passengers about tourism in Indonesia and attract local and foreign tourists to visit tourist attractions in Indonesia. Additional information about Indonesia's historical, cultural, and culinary areas along with the price details may accommodate the tourists' need for information. By reading some rubrics of LionMag, target market may know the various natural beauties, cultures in Indonesia that are preserved and very potential to be visited. Even nature tourism can be entertaining with consideration 
of the facilities, and historical and cultural tours that can add knowledge. In addition, there are more reviews about the typical Indonesian cuisine that is worth a try by foreign and local tourists.

The magazine can support tourism marketing because it provides various information about interesting tourist attractions, how to go there, vehicles, accommodation, culinary, cultural performances and other practical tips for tourists. The information will be useful for decision making about tourism product development and finding the right marketing strategy to meet the changing needs of travelers.

Any tourists who plan to travel will definitely go through the decision-making process of their tourist destination. The LionMag magazine covers all of the needs as one complete but still simple media. This feature is maintained by LionMag through the consistency of rubric and content. Tourists will more easily build their perception of the destinations that may be the destination of their visit. This perception is generated by individual preferences, prior experience and information obtained.

As recognized for being able to accommodate the reader's need, the publisher then uses information from agents to determine strategies for marketing and product policies. Publisher positions LionMag with a focus on the look and content of the rubric that matches with travelers' expectations. Some agents are trusted to be highly competent in providing advice related to circulation, cover design (magazine cover) even up to the news to be covered. The implications are a good rubric view, an attractive cover design and can be guidance for potential tourists to explore Indonesia.

There are 4 (four) things that influence the decision process of tourists, among others: attitude, perception, motivation, and image. Besides, the attraction also affects the motivation of tourists in making decisions about tourist destinations to be visited. Therefore, LionMag continues to strive to be creative in providing information needed by local and foreign tourists. Each rubric is tailored to a language that is easy to understand and is targeted to the upper middle class in order to invite/persuade tourists to come. In other words, the discourse on LionMag which is also part of the marketing communication strategy is a combination of four types of structure, namely the structure of ideas, the process of author thinking, the choice of language and the situation or expectations of tourists and magazine design tailored to the theme.

\section{CONCLUSIONS}

LionMag continues to strive to be creative in provid- ing information needed by both local and foreign tourists. Each rubric is tailored to a language that is easy to understand, targeted to the upper middle class with the rubric idea that leads to an invitation/persuasion. In other words, the discourse on LionMag which is also part of the marketing communication strategy is a combination of four types of structure, namely the structure of ideas, the process of author thinking, the choice of language and the situation or expectations of tourists and magazine design tailored to the theme.

The LionMag magazine needs to reduce proactive language that leads to counter ideologies against a particular social class because of the need to penetrate the target market. Nevertheless, the interpretation of discourse depends on the discourse presented by the author. The progress of people's knowledge depends on the knowledge and information presented by the media. This is something needs to be aware of.

\section{REFERENCES}

Fill, C. 1995. Marketing Communication: Framework, theories and Application. London: Prentice Hall.

Kotler, P., \& Keller, K. L. 2011. Marketing Management. $14^{\text {th }}$ edition, Pearson.

Martiman. 2014. Strategi Pemasaran Barang dan Jasa Perusahaan Melalui Media Iklan. Jurnal Ilmiah Widya 2(2): 5563.

McIntosh, R.W. \& Goeldner, C.R. 1986. Tourism: Principles, Practices and Philosophies 5th ed. New York: John Wiley $\&$ Sons.

Richardson, J.E. 2007. Analyzing Newspapers: An Approach From Critical Discourse Analysis. New York: Palgrave Macmillan.

Setiawan, Y.B. 2011. Analisis Wacana Kritis Pemberitaan Kekerasan Berbasis Gender di Surat Kabar Harian Suara Merdeka. Jurnal Ilmiah Komunikasi MAKNA 2(1).

Shimp, T. A. 2003. Periklanan Promosi Aspek Tambahan Komunikasi Pemasaran Terpadu Jilid I. Jakarta: Erlangga.

Siahaan, S. L. 2008. Visit Indonesia Year 2008: Suatu Tinjauan Dari Perspektif Pemasaran Destinasi Pariwisata. Majalah Ilmiah Panorama Nusantara 4(January-June): 7-15.

Sutisna, S. 2002. Perilaku Konsumen \& Komunikasi Pemasaran. Bandung: PT Remaja Rosdakarya.

Titscher, S., Meyer, M., \& Vetter, R. W. 2012. Methods of Text and Discourse Analysis. London: SAGE Publication.

Wahab, S. 1975. Tourism Management, Tourism International Press. Turin: Tourism International Press.

Wodak, R., \& Meyer, M. 2016. Critical Discourse Studies: History, Agenda, Theory and Methodology. London: SAGE Publication.

Yudarnadi, F., \& Santoso, N. W. 2015. Pembuatan Majalah Digital Magazine Sebagai Media Promosi Wisata dan Budaya Karesidenan Madiun Dengan Menggunakan Software Pengolah Grafis. Jurnal Ilmiah Teknologi dan Informasi ASIA 9(1). 